\title{
Paulsenella Chatton (Dinophyta), ectoparasites of marine diatoms: development and taxonomy*
}

\author{
G. Drebes ${ }^{1} \&$ E. Schnepf ${ }^{2}$ \\ ${ }^{1}$ Biologische Anstalt Helgoland (Litoralstation); D-2282 List/Sylt, Federal Republic of \\ Germany \\ ${ }^{2}$ Zellenlehre, Universität Heidelberg; Im Neuenheimer Feld 230, D-6900 Heidelberg, \\ Federal Republic of Germany
}

\begin{abstract}
All members of the dinophyte Paulsenella are ectoparasites on marine planktonic diatoms. At present three species are known, two of which are described here for the first time. The taxonomy of the type species, $P$. chaetoceratis, is paid critical attention. The species are clearly distinguished by their host specificity and additionally by differences in morphology, especially of the trophonts. Using clonal cultures the life cycles of the three species are compared. The vegetative development may be interrupted by formation of temporary and resting cysts. In ageing cultures, stages with nuclear cyclosis occur, believed to indicate meiosis. In $P$. vonstoschii, the meiospores are capable of developing into resting cysts. As yet, knowledge on sexual reproduction is still incomplete.
\end{abstract}

\section{INTRODUCTION}

In 1911, Paulsen described an ectoparasitic dinophyte from coastal waters of eastern Greenland, preying on Chaetoceros borealis and $C$. decipiens, and named it tentatively Apodinium (?) chaetoceratis. In a monograph on parasitic dinophytes, Chatton (1920) transferred it to a new genus, Paulsenella Chatton. Drebes (1974) reported $P$. chaetoceratis from the North Sea where it was found to feed on C. decipiens, and also, in one single case only, on the sporadic $C$, borealis. In addition, he noticed similar parasites on other diatoms like Streptotheca thamesis, Eucampia zodiacus, and Cerataulina pelagica. Aleem (1979) observed $P$. chaetoceratis in the Gulf of Guinea.

There are also some unpublished observations worth mentioning. In 1953, Stosch (pers. comm.) found near Sylt a summer population of Streptotheca thamesis almost completely eliminated by Paulsenella. In laboratory cultures with this parasite he obtained a weak infection on Bellerochea malleus and Lithodesmium undulatum. In 1986, Rut Akselman (Mar del Plata, Argentina) informed us that at the port of Mar del Plata natural populations of Lithodesmium undulatum were infected by Paulsenella in two successive summers.

Simultaneous cultivation of hosts and parasites allowed a detailed study of Paulsenella. We investigated the life cycle (Drebes, 1984), phagotrophy and development

- Dedicated to Dr. Dr. h. c. P. Kornmann on the occasion of his eightieth birthday. 
(Drebes \& Schnepf, 1982), the fine structure (Schnepf \& Deichgräber, 1984; Schnepf et al., 1985), and chemotaxis and appetence (Schnepf \& Drebes, 1986) of Paulsenella parasitizing Streptotheca. In addition, we followed the special mode of food uptake of Paulsenella on Chaetoceros (Schnepf et al., 1988), and suspected the existence of more than one species (cf. Drebes, 1984). In the present study, morphology, development, host range and feeding mode of the various forms are compared. Besides $P$. chaetoceratis that preys on Chaetoceros decipiens, two new species, P. kornmannii on Eucampia zodiacus, and $P$. vonstoschii on $S$. thamesis are described for the first time.

\section{MATERIALS AND METHODS}

The hosts as well as the parasites were isolated from the Wadden Sea near List/Sylt (North Sea) and maintained as clonal cultures in Petri dishes in a nutrient-enriched $\mathrm{f} / 2$ medium (McLachlan, 1973) at $15^{\circ}$ or $18^{\circ} \mathrm{C}$, and were illuminated $14 \mathrm{~h}$ per day. The parasites were grown together with the host species on which they were found: Chaetoceros decipiens Cleve, Eucampia zodiacus Ehrenberg, and Streptotheca thamesis Shrubsole.

To study the host range we used diatoms freshly isolated from plankton samples or from cultures. They were added to starved cultures of the parasite consisting predominantly of free swimming dinospores. The purpose of these feeding experiments was to determine the potential host range, which may be broader than the actual host range in the natural environment.

Living material was observed at room temperatures using seawater immersion objectives (Leitz). For epifluorescence, a Zeiss IM 35 microscope served to detect polysaccharides after treatment with Tinopal UP (Cibd/Geigy) or Calcofluor White.

For further details of the methods used including electron microscopy, refer to previous publications by the authors (see "Introduction").

\section{RESULTS}

Paulsenella vonstoschii (Figs 29-41) has been studied extensively. Its structure and development have been described in detail in previous publications (see "Introduction"), especially by Drebes \& Schnepf (1982). These publications provide a basis for comparison with the other species.

\section{Host range}

P. vonstoschii was isolated from and grown on Streptotheca thamesis (see also Drebes, 1984). Not all the clones of this diatom were readily accepted as a host. A weak infection was obtained on Neostreptotheca subindica Stosch, Bellerochea malleus (Brightwell) Heurck, and Lithodesmium undulatum Ehrenberg. Cerataulina pelagica (Cleve) Hendey, Chaetoceros convolutus Castracane, C. decipiens, Coscinodiscus wailesii Gran \& Angst, and Eucampia zodiacus did not attract $P$. vonstoschii.

$P$. chaetoceratis (Figs 1-16) was found attached to the setae of Chaetoceros decipiens, but unexpectedly (cf. Paulsen, 1911) it did not attack C. borealis Bailey when fresh isolates from plankton samples were offered. Not accepted as hosts were furthermore $C$. densus Cleve, C. teres Cleve, Ditylum brightwellii (West) Grunow, Eucampia zodiacus, 
Schroederella schroederi (Bergon) Pavillard, Stephanopyxis turris (Grev. \& Arn.) Ralfs, Streptotheca thamesis, and Thalassiosira rotula Meunier.

P. kornmannii (Figs 17-28) parasitizes Eucampia zodiacus. The closely related E. groenlandica Cleve was not infected, and further experiments to cultivate the parasite on Chaetoceros decipiens, C. teres, Ditylum brightwellii, Schroederella schroederi, and Stephanopyxis turris also failed.

\section{Dinospores}

The motile dinospores of the three species are gymnodinoid, biflagellate, athecate, lacking plastids, and similar in outline (Figs 1-3, 7-9, 21-23, 25, 29, 35). The girdle is equatorial, and the sulcus is restricted to the ventral side of the hypocone. The longitudinal flagellum measures 20-25 $\mu \mathrm{m}$. The hypocone containing the nucleus is nearly hemispherical in each species. Only in large dinospores of $P$. kornmannii is it somewhat higher and slightly conical in shape. The size of the dinospores varies between $14-18 \mu \mathrm{m}$ (length) and 12-16 $\mu \mathrm{m}$ (width) in $P$. vonstoschii, $15-19 \mu \mathrm{m}$ and $12-15 \mu \mathrm{m}$ resp. in $P$. kornmannii, and $12-15 \mu \mathrm{m}$ and $10-13 \mu \mathrm{m}$ resp. in $P$. chaetoceratis. The size data apply to dinospores of young and healthy cultures, whereas extreme sizes are only met in ageing cultures.

\section{Chemotaxis, attachment, peduncle}

The parasites are chemotactically attracted by short-lived secretory products of their hosts which, at least in $P$. vonstoschii, are presumably components of the diatom mucilage. When the dinospores of all three species perceive the host, they swim no longer in slightly curved tracks but in narrow helices to approach the host. They seem to be attracted by the region where the attractant has its highest concentration, i.e. where it is released through the diatom shell into the medium. That is in Streptotheca and Eucampia the girdle region, in the first one predominantly near the nucleus (Figs 17, 18, 29-31). In both species, the feeding tube is not protruded until the dinospore has definitely attached to the host.

In contrast, the chemotactically attracted dinospores of $P$. chaetoceratis project the feeding tube, recognizable as a stiff rod measuring about $6-8 \mu \mathrm{m}$ in length (Fig. 3), prior to attachment. The host cell is first probed with the tip of the feeding tube, contact being gained most extensively with the setae and, to a much lesser degree, with the labiate process in the valvar centre. Furthermore, in ageing diatom cultures, the girdle region appears to be attractive too. Obviously, these regions are the secretory sites of the attractants. The same sites are possibly used by the host for the uptake of nutrients. Thus, one might speculate that the setae of Chaetoceros are not only used to keep the cell chains floating but they may also serve the purpose of nutrient uptake.

The dinospores of $P$. chaetoceratis establish the first firm contact when the tip of the feeding tube pierces the seta. The parasite's body does not touch and is not fixed to the seta until the feeding tube has prolonged itself into the interior of the seta. The time needed for the feeding tube to pass through the seta into the host cell is generally about one hour, but this depends on the site of entry.

To enter the seta, the dinospores use the apical opening and the lateral fenestration of the latter. They attach especially to the distal region of the setae because the apertures there are larger (Figs 1-4). Setae that are not quite fully developed are preferred (Figs 4 , 
$12,13)$. According to the length of the setae, the feeding tube can reach a length of about $150 \mu \mathrm{m}$. In ageing cultures, the diatom cells tend to break down in the girdle region, thus enabling the dinospores to penetrate here too: In these cases, the feeding tube is not only relatively long but also curved.

In $P$. chaetoceratis, the peduncle (Figs 1,2 ) consists only of the cytoplasmic feeding tube, which is not surrounded by a sheath.

$P$. vonstoschii invades the host cell through the intercingular slit (Figs 30,31 ). The dinospores attach to the hypotheca of the host cell with their hypcone oriented toward the epitheca. Granules of a strongly light-refractive, presumably lipoproteidic, material are secreted along the feeding tube when piercing the host (Figs $31,36,38$ ). This refractive material has a rod- or crook-like arrangement (Drebes \& Schnepf, 1982: "crook"). It persists for a very long time in the emptied host cell, conspicuously indicating that the diatom cell has been attacked by $P$. vonstoschii. In addition, the feeding tube has a thin sheath at its proximal part. This sheath envelopes the feeding tube in the intercingular slit region and, in a more delicate form, also the proximal part of its free end inside the host cell. It stains with Calcofluor White ( $=$ Tinopal) indicating the presence of cellulose or a similar polysaccharide (Fig. 37). Because of its delicacy, the sheath is hardly recognizable at all in some cells.

Similarly, the dinospores of $P$. kornmannii also penetrate the host cell through the intercingular slit (Figs 17, 18). The peduncle of this species, however, lacks the refractive granules found in $P$. vonstoschii. The feeding tube sheath is conspicuous and well visible within the empty host cell after the feeding tube has retracted (Fig. 24). The sheath consists of three parts. The proximal part is thin-walled, $2-6 \mu \mathrm{m}$ long, and not laterally attached to the diatom shell. Therefore, the body of the trophont as well as the subsequent cyst stage are in no direct contact with the theca. In consequence, the cysts easily detach (Figs 25, 26, 28). The middle part (ca $6 \mu \mathrm{m}$ long) of the sheath passes through the intercingular slit. Its wall is extremely thick and stains with Calcofluor White. It is soluble in zinc-chlor-iodide. The distal part $(6-8 \mu \mathrm{m}$ long) is again thin-walled and extends, slightly curved, into the cell lumen. The sheath develops when the feeding tube penetrates the host cell.

\section{Host reaction, food uptake}

When the feeding tube has reached the cell lumen, the protoplast of the host cell begins to plasmolyse. In Streptotheca and Chaetoceros the vacuoles shrink and eventually disappear (Figs 1, 2, 30, 31). In Eucampia, the cytoplasm, chloroplasts, and the nucleus agglomerate at the mouth of the feeding tube. The vacuoles are pushed toward the opposite side, where they frequently become separated from the bulk of the cytoplasm (Figs 17-19). In the case of a simultaneous attack by two parasites, the cytoplasm concentrates near both feeding tubes, leaving the vacuoles in between.

The process of sucking up the host cytoplasm through the feeding tube channel appears to be similar in all three species. In $P$. vonstoschii and $P$. kornmannii, the transport of a single food particle via the feeding tube takes place in only 3-8 sec. It takes considerably longer in $P$. chaetoceratis because of the latter's extremely elongated feeding tube, though the rate of particle flow is nearly the same.

The food vacuoles develop in the epicone of the parasite (Figs 1, 18). In P. vonstoschii 
and $P$. kornmannii, the host cytoplasm is included within a single food vacuole, whereas in $P$. chaetoceratis it is distributed among several smaller food vacuoles (Figs 1,4).

Generally, the attacked host cell is completely sucked out (Fig. 31). However, in extremely large Streptotheca cells resulting from recent auxospore formation, a portion of cytoplasm can be left behind, which may regenerate if the host nucleus is still present. In these cases, $P$. vonstoschii behaves as a parasite in a strict sense, as the host is only damaged and not killed.

Food uptake enlarges the trophont considerably, whereby the food vacuole finally occupies most of the cell volume (Fig. 31). Assuming a globular shape, the trophont loses the flagella, early in $P$. vonstoschii, relatively late in the two other species. Young trophonts begin to become surrounded by material that is Calcofluor White-positive. Once food uptake has finished, the feeding tube is retracted, the trophont becomes encysted, and digestion begins.

\section{Digestion, development of cysts and dinospores}

In $P$. chaetoceratis digestion commences as soon as a food vacuole has left the feeding tube channel. Thus, a cell contains food vacuoles at various stages of digestion. Within the encysted trophont (primary cyst), the food vacuoles shrink during digestion, while the protoplast of the parasite enlarges correspondingly (Figs 20,32). Especially the amount of refractive granules of reserve material increases. After $6-10 \mathrm{~h}$ the nucleus and the protoplast of the primary cyst divide. The division furrow develops excentrically, starting at the nuclear anaphase from the side of the dividing nucleus.

Both daughter cells form a new thick cyst wall each, and become secondary cysts (Figs $4,21,33$ ). They remain initially enclosed within the primary cyst wall, which later becomes thinner and eventually disappears. Then, though in P. kornmannii only exceptionally, one or both secondary cysts may divide again resulting in tertiary cysts (Figs 5 , 34). In rare cases, $P$. chaetoceratis may even form quartary cysts (Fig. 6).

The final cyst stage has the function of a dinosporangium (zoosporangium). Thus, the number of dinospores arising from a single trophont is determined by the number of cysts formed before. That means, as a rule, for $P$. kornmannii 2 or 4 , seldomly 8 , in $P$. vonstoschii, 4,6 or 8 , and in $P$. chaetoceratis 4,8 or 16 dinospores as a result of one feeding act.

As the dinosporangial cysts lack preformed apertures, the dinospores are simply released by a rupture of the cyst wall (Figs $7,8,21$ ). While developing to their final shape they swim around (Fig. 35), whereas $P$. kornmannii dinospores remain connected with the remnants of the dinosporangium for some time (Figs 22, 23).

In $P$. vonstoschii one dinospore contains as a rule the residual body of the food vacuole, whereas in $P$. kornmannii the residual body is frequently extruded during the last cell division (Fig. 23). In $P$. chaetoceratis the residual bodies are distributed among the dinospores, so that most of them get at least one (Figs 7,8 ).

After a certain postmaturation phase, the dinospores are ready to attack a new host cell. The complete vegetative developmental cycle (Fig. 42) takes about one day or more, depending on temperature. 


\section{Nuclear cyclosis and sexuality}

Nuclear cyclosis in dinophytes is believed to represent a stage of the meiotic prophase (Stosch, 1972, 1973). A nucleus in cyclosis is considerably larger than a normal (haploid?) nucleus, and is roundish or ovoid (Figs 12, 13, 27, 28, 38, 39). Furthermore, in contrast with a normal one, it is, whether in interphase or mitosis, distinctly separated from the cytoplasm. During cyclosis, the chromosomes are extremely thin and elongate. The chromosomal mass and the nucleoli rotate and whirl around within the nuclear envelope at a higher speed at the periphery than in the interior. This spectacular process lasts several hours and can easily be followed by direct observation on living material.

Nuclear cyclosis takes place in the primary cyst at a stage, when the food vacuole is shrinking (Figs 27, 38). A normal cell would become mitotic at this time. However, in $P$. chaetoceratis, cyclosis is predominantly observed in younger cysts and even in feeding trophonts (Fig. 12), In $P$. vonstoschii cyclosis may occasionally occur in small free-lying cysts which obviously were not directly derived from trophonts.

Cyclosis is followed by nuclear division (Fig. 40). As a rule we observed two subsequent divisions resulting in 4 dinospores, which may be termed meiospores. In $P$. vonstoschii they soon settle down and may develop into resting cysts (Fig. 40 , see below). However, in this species as well as in $P$. chaetoceratis we observed also the offsprings of cells in cyclosis attacking a new host cell and becoming again trophonts.

Cells with nuclear cyclosis are met predominantly in dense, ageing cultures in which the food supply is reaching exhaustion. Maximum occurrence is between 10.00 and $15.00 \mathrm{~h}$ (light period: $8.00-22.00 \mathrm{~h}$ ). There are some primary indications of sexual processes preceding meiosis. In $P$. vonstoschii and $P$. chaetoceratis, we observed putative sexual stages (Fig. 11). They are nearly exclusively found in the middle of the dark period, and mainly in dense cultures with starved dinospores. Under these conditions one can observe dense swarms of 10-100 dinospores swimming quickly around a relatively immobile, only slightly quivering cell (Fig. 10). The swarms remain together for 5-20 sec,, and then separate, whereupon the formerly surrounded cell regains its normal motility. The dinospores involved in these short-term swarms vary in size, both the mobile and the immobile ones. In one case, we saw a surrounded cell contacting one of the surrounders via the tips of the longitudinal flagella. Within $20 \mathrm{~min}$. they approached each other, and then seemed to fuse in the region of the flagellar insertion. Unfortunately, the movement of the cells prevented a following up of the further development of this cell couple. Similar fusion stages were found several times, but again their further fate remains unknown to date. Confusion of these stages with misdivisions, resulting from an increasingly disturbed dinospore formation in ageing cultures, is easily possible. Thus, our observations on sexual processes are still unsubstantial.

\section{Resting cysts, temporary cysts}

In ageing cultures, especially when the host cells start deteriorating, the parasites interrupt development by forming resting cysts and temporary cysts (Figs 16, 25, 26, 41). Resting cysts have a thick, occasionally multilamellate wall. In size and shape they resemble big swollen dinospores, and they are crowded with refractive granules of reserve material. In $P$. vonstoschii, the development of resting cysts could be related to meiosis (nuclear cyclosis). Single primary cysts (meiocysts) displaying cyclosis were 
isolated and observed to give rise to four dinospores (meiospores) each. After a short motile period $(<1$ day), the swarmers settle down to become resting cysts. It is as yet unclear, whether the formation of resting cysts is obligatorily preceded by meiosis, and whether in reverse, meiospores always result in resting cysts. Resting cysts in nature are supposed to survive longer periods of unfavourable conditions. Under culture conditions, we could force the resting stages to germinate after a few days. When changing the nutrient solution, one dinospore (or more?) emerged from a resting cyst.

Another cyst type are the temporary cysts, which also arise from dinospores. These cysts are thin-walled, short-lived, and lack conspicuous granules of reserve material. A temporary cyst germinates by releasing a single dinospore, which may repeatedly encyst and excyst again. Thereby, the dinospore becomes smaller and smaller, in extreme cases finally including almost only the nucleus. Temporary cysts may be a useful response of the parasite especially for withstanding short-term changes in the environment.

\section{Taxonomy of the species \\ Paulsenella Chatton}

Ectoparasitic on marine diatoms. Dinospores athecate, gymnodinoid, biflagellate, apoplastidic. Girdle median, sulcus restricted to the hypocone. Penetration into the host by a peduncle. Dinospore transformed into a trophont sucking up cytoplasm of the host. Further development within cyst stages. Trophont becomes a primary cyst, which may develop secondary, tertiary, or quartary cysts. The final cysts represent dinosporangia, each giving rise to two dinospores. Occasionally, nuclear cyclosis in primary cysts or (more seldom) in trophonts. Interruption of vegetative development by resting and temporary cysts.

Paulsenella chaetoceratis (Paulsen) Chatton (Figs 1-16)

Host: Chaetoceros decipiens. Dinospores 12-15 $\mu \mathrm{m}$ long, 10-13 $\mu \mathrm{m}$ wide, epi- and hypocone hemispherical. Peduncle already formed before attachment to the host. Penetration through the host setae, peduncle elongating up to $150 \mu \mathrm{m}$. Trophont with several food vacuoles, later distributed among the dinospores. Trophont develops into 2 or 4 , seldomly 8 , cysts (dinosporangia). Nuclear cyclosis predominantly in trophonts or young primary cycts.

Basionym: Apodinium (?) chaetoceratis Paulsen

Synonym: Vampyrella chaetoceratis (Pauls.) Ostenfeld

Paulsenellakornmannii Drebes \& Schnepf sp. nov. (Figs 17-28)

Host: Eucampia zodiacus. Dinospores 15-19 $\mu \mathrm{m}$ long, 12-15 $\mu \mathrm{m}$ wide, epicone hemispherical or conical, hypocone hemispherical. Peduncle formed after attachment to the host. Penetration through the intercingular slit in the girdle region. Wall of the peduncle thickened in the middle part. Trophont containing only a single large food vacuole. Residual body of the food vacuole generally excluded during dinospore formation. Trophont develops into 1 or 2, seldomly 4, cysts (dinosporangia). Nuclear cyclosis in old primary cysts.

Type locality: German Bight near List/Sylt.

Latin diagnosis

Hospes: Eucampia zodiacus. Longitudinis latitudinisque dinosporarum 

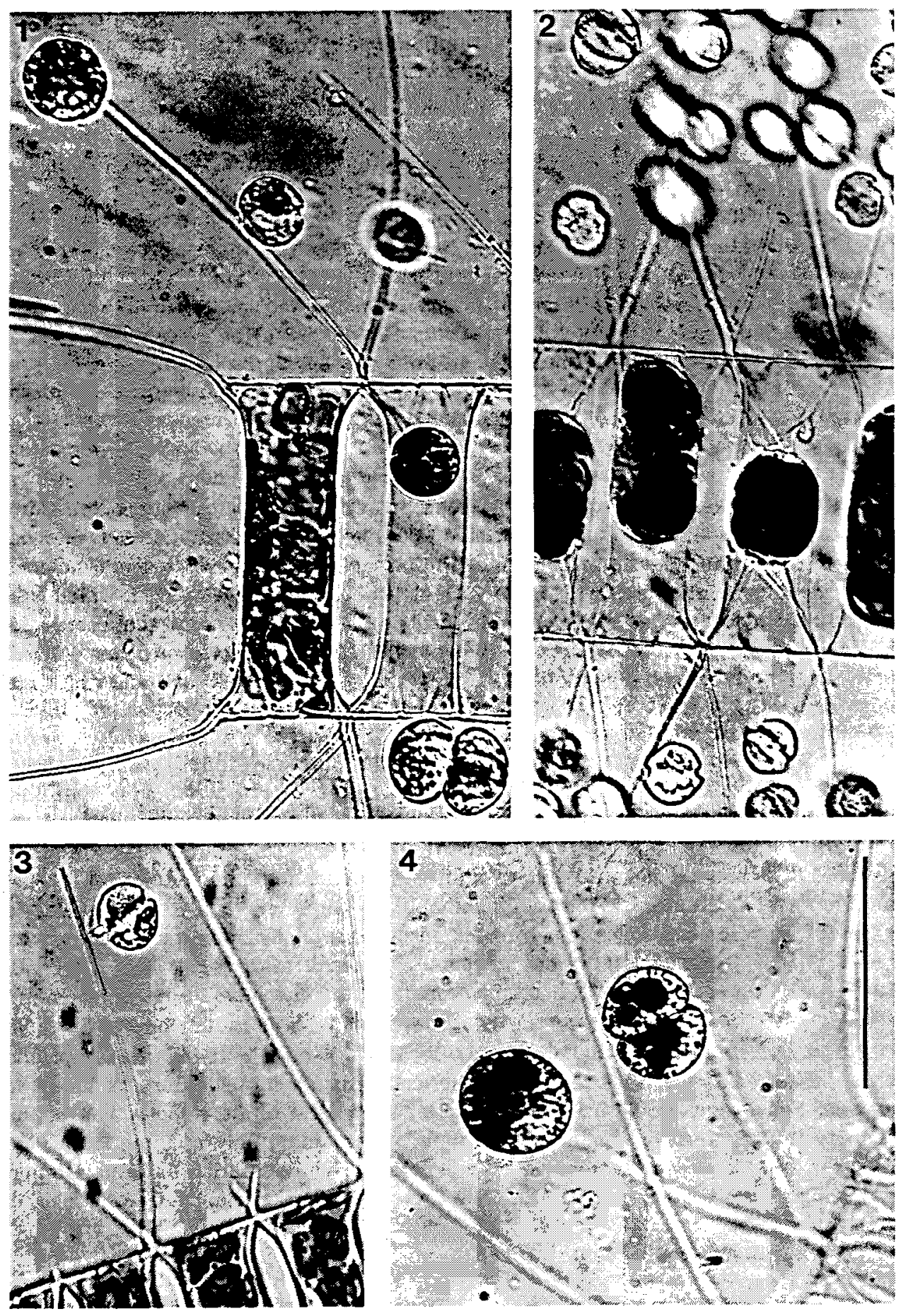
15-19 × 12-15 $\mu \mathrm{m}$, epicono hemisphaerico vel conico, hypocono hemisphaerico. Pedunculus post adhaerescendum ad hospitem formatus, penetrat cellulam hospitem inter epicingulum hypocingulumque, muro incrassato in parte media. Trophontus cum vacuola digestiva magna unica. Corpus residuus vacuolae digestivae expulsum plerumque tempore nascendi dinosporarum. Trophontus generat 1 vel 2, rarus 4 cystas (dinosporangia). Cyclosis nuclei in cystis primariis vetis.

Locus typicus: In mare sinu germanico iuxta List/Sylt.

Typus: Figurae nostrae 17-28.

The species is dedicated to the German phycologist, Dr. Dr. h. c. Peter Kornmann (Helgoland) on the occasion of his 80th birthday.

Paulsenella vonstoschii Drebes \& Schnepf sp. nov. (Figs 29-41)

Host: Streptotheca thamesis, Neostreptotheca subindica, Lithodesmium undulatum, Bellerochea malleus. Dinospores 14-18 $\mu \mathrm{m}$ long, 12-14 $\mu \mathrm{m}$ wide, epi-and hypocone hemispherical. Peduncle formed after attachment to the host. Along the peduncle a rodlike structure consisting of refractive granules. Penetration through the intercingular slit in the girdle region. Trophont containing only a single large food vacuole. One dinospore receives the residual body of the food vacuole. Trophont develops. into 2, 3, or 4 cysts (dinosporangia). Nuclear cyclosis in old primary cysts.

Type locality: German Bight near List/Sylt.

Synonym: Paulsenella cf. chaetoceratis (Drebes \& Schnepf, 1982).

Latin diagnosis

Hospes: Streptotheca thamesis, Neostreptotheca subindica, Lithodesmium undulatum, Bellerochea malleus. Longitudinis latitudinisque dinosporarum 14-18 $\times 12-14 \mu \mathrm{m}$, epicono hypoconoque hemispherico. Pedunculus post adhaerescendum ad hospitem formatus. Structura bacilliformis ex granulis refractivis secundum pedunculum. Pedunculus penetrat cellulam hospitem inter epicingulum hypocingulumque. Trophontus cum vacuola digestiva magna unica. Corpus residuus vacuolae digestivae inclusum in dinospora una. Trophontus generat 2, 3 vel 4 cystas (dinosporangia). Cyclosis nuclei in cystis primariis vetis.

Locus typicus: In mare sinu germanico iuxta List/Sylt.

Typus: Figurae nostrae 29-41.

The species is dedicated to the German phycologist, Prof. Dr. Hans-Adolf von Stosch (Marburg/L.), who died on 8 January 1987, at the age of 78.

\section{DISCUSSION}

The three Paulsenella species - two of which are described herein for the first time resemble one another in structure as well as in the cardinal elements of their life cycle (Figs 42,43 ). However, differences in some structural and developmental details justify a separation into different species. In plankton samples they can be easily identified by

Figs 1-4. Paulsenella chaetoceratis on Chaetoceros decipiens. Fig. 1. Trophonts sucking out a cell of the diatom chain. Below, two secondary cysts. Fig. 2. Multi-infection; note the thread-like dinospore peduncles running to the shrinking protoplasts of the host. Fig. 3. Dinospore contacting via a peduncle a seta of Chaetoceros. Fig. 4. Primary cyst and two secondary cysts. Scale bar $=50 \mu \mathrm{m}$ 

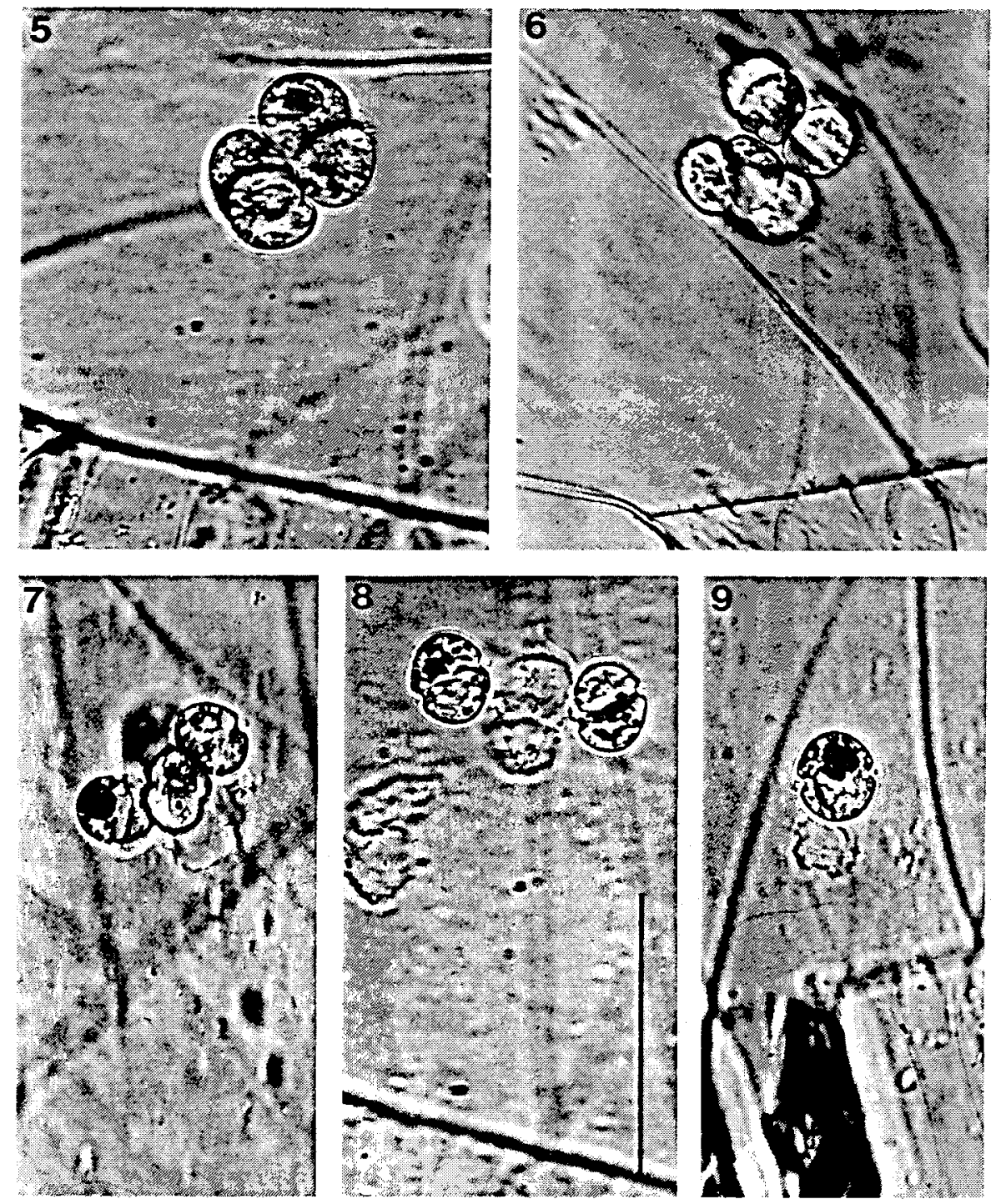

Figs 5-9. Paulsenella chaetoceratis on Chaetoceros decipiens. Fig. 5. Four tertiary cysts. Fig. 6. Eight quartary cysts. Fig. 7. Release of four dinospores. Fig. 8. Two freshly released dinospores swimming around the ruptured envelopes of the dinosporangia (secondary cysts). Fig. 9. Liberation of a dinospore from a single (temporary?) cyst. Scale bar $=50 \mu \mathrm{m}$

their host specificity. The host ranges were obtained in the course of continuous observations over two decades on North Sea phytoplankton of the German Bight. In addition, feeding experiments using a variety of clonal diatom cultures and fresh isolates from the plankton were carried out in order to delimitate the species on the basis of their host specificity. 

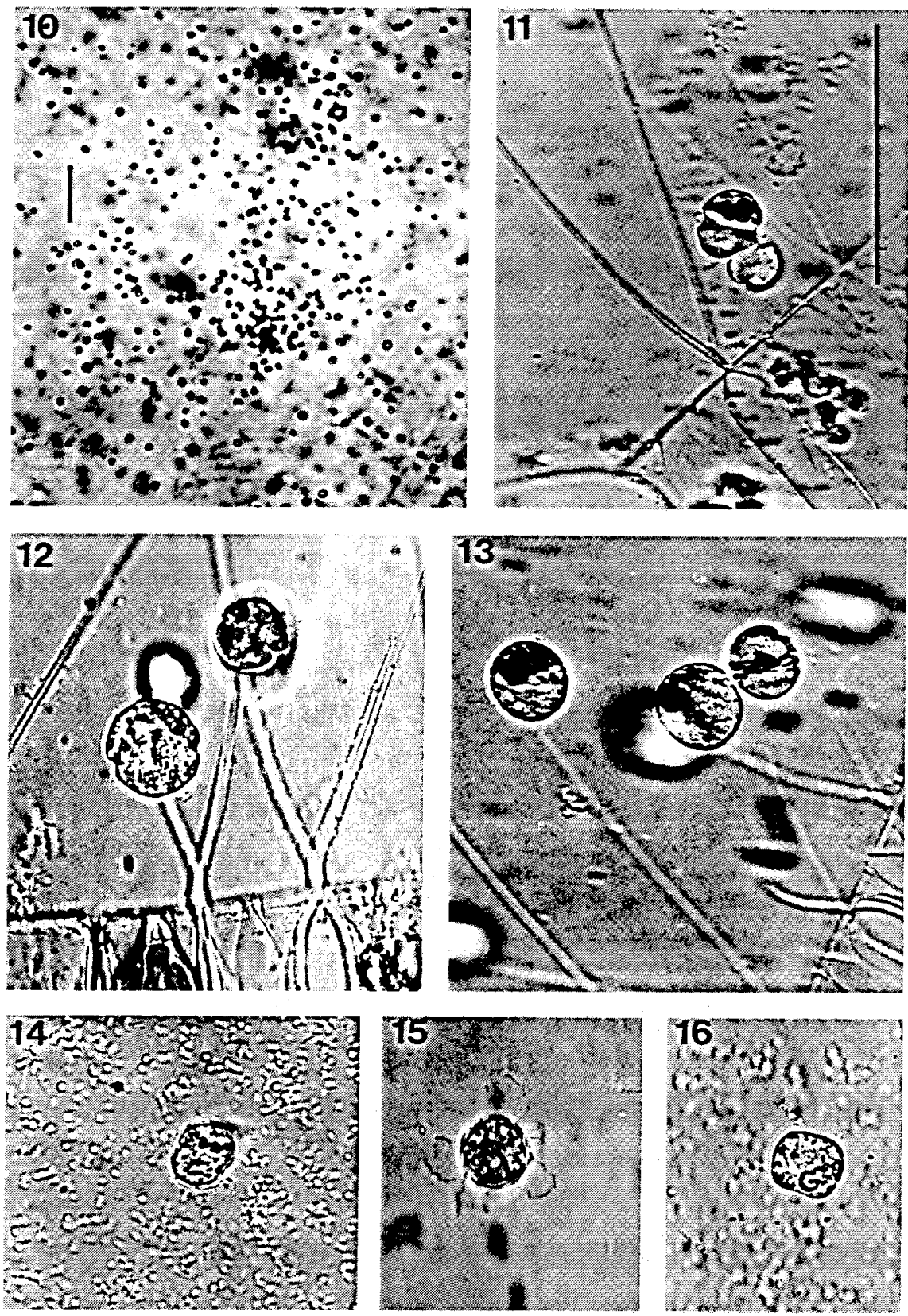

Figs 10-16. Paulsenella chaetoceratis on Chaetoceros decipiens. Fig. 10. Aggregation of sexually determined dinospores (gametes) during the dark phase. Fig. 11. Couple of dinospores, assumed to be copulating gametes. Fig. 12. The larger trophont to the left in nuclear cyclosis. Fig. 13. Young primary cysts (the two left ones in focus) in nuclear cyclosis. Fig. 14. Resting cyst. Fig. 15. Resting cyst surrounded by ruptured temporary (?) cyst envelopes. Fig. 16. Temporary cyst. Fig. 10: Scale bar $=100 \mu \mathrm{m}$. Figs $11-16:$ Scale bar $=50 \mu \mathrm{m}$ 
G. Drebes \& E. Schnepf
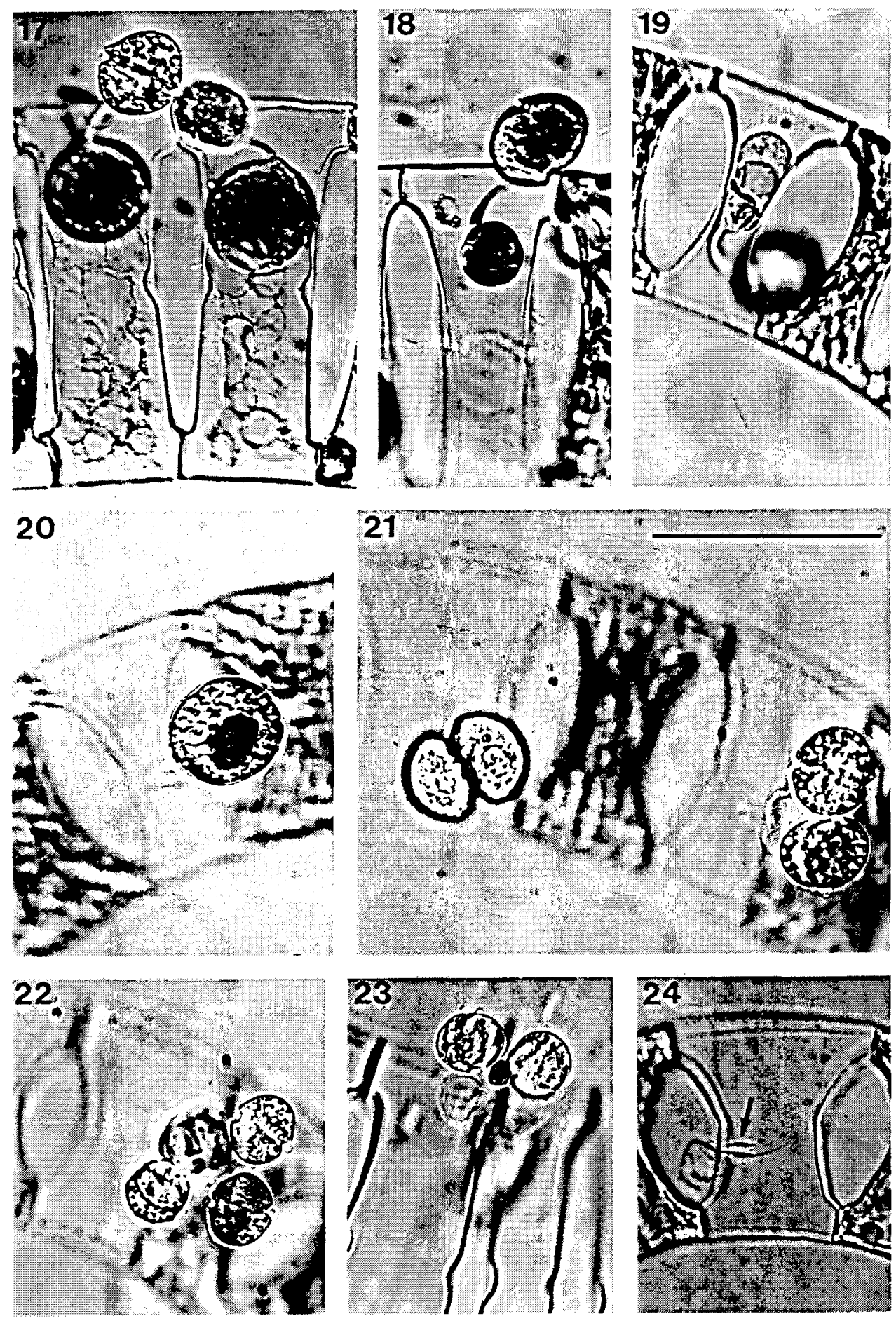

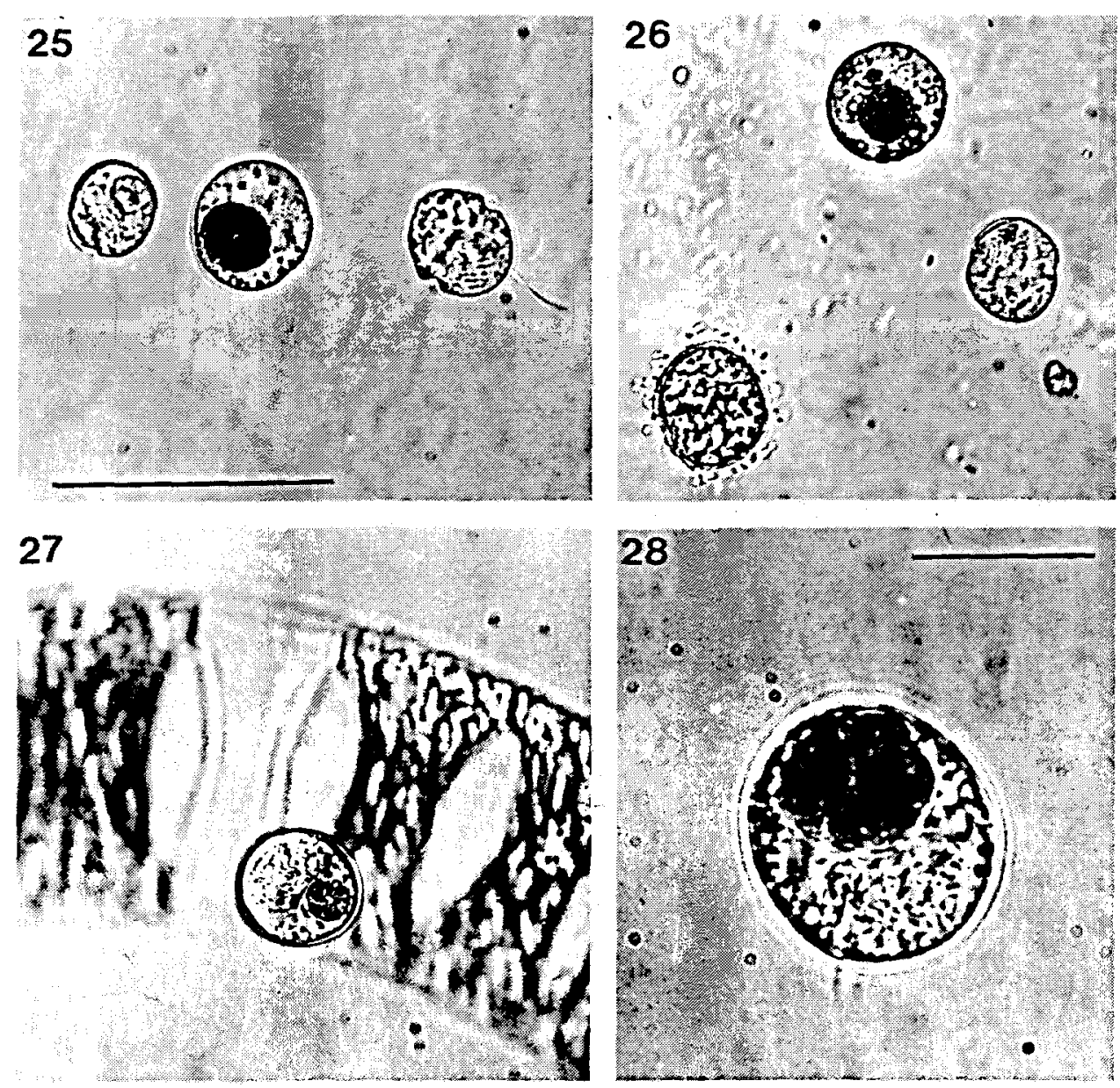

Figs 25-28. Paulsenella kornmannii on Eucampia zodiacus. Fig. 25. Temporary cyst, primary cyst, dinospore (from left to right). Fig. 26. Resting cyst, primary cyst, temporary cyst (from left to right). Fig. 27. Primary cyst in nuclear cyclosis. Fig. 28. Detached primary cyst in nuclear cyclosis. Figs 25-27: Scale bar $=50 \mu \mathrm{m}$. Fig. 28: Scale bar $=20 \mu \mathrm{m}$

As a result, the host ranges were found to be very narrow, restricted to only a single (or two?) host species in P. chaetoceratis and P. kornmannii. Likewise, we observed that $P$. vonstoschii in plankton samples of the Wadden sea near Sylt was attached to Streptotheca thamesis only; but, in culture experiments we achieved a weak infection

Figs 17-24. Paulsenella kornmannii on Eucampia zodiacus. Fig. 17. Two trophonts sucking on large Eucampia cells. Fig. 18. Trophont at an advanced stage, a chloroplast is just passing through the peduncle. Fig. 19. Trophont (out of focus) completely sucking out a host cell. Fig. 20. Primary cyst. Fig. 21. Two secondary cysts and two dinospores emerging from a primary cyst (right). Fig. 22. Four dinospores released from two secondary cysts. Fig. 23. Two released dinospores with the extruded residual body between them (dark spot). Fig. 24. Empty cyst (out of focus) with a peduncle showing the swollen middle part (arrow). Scale bar $=50 \mu \mathrm{m}$ 

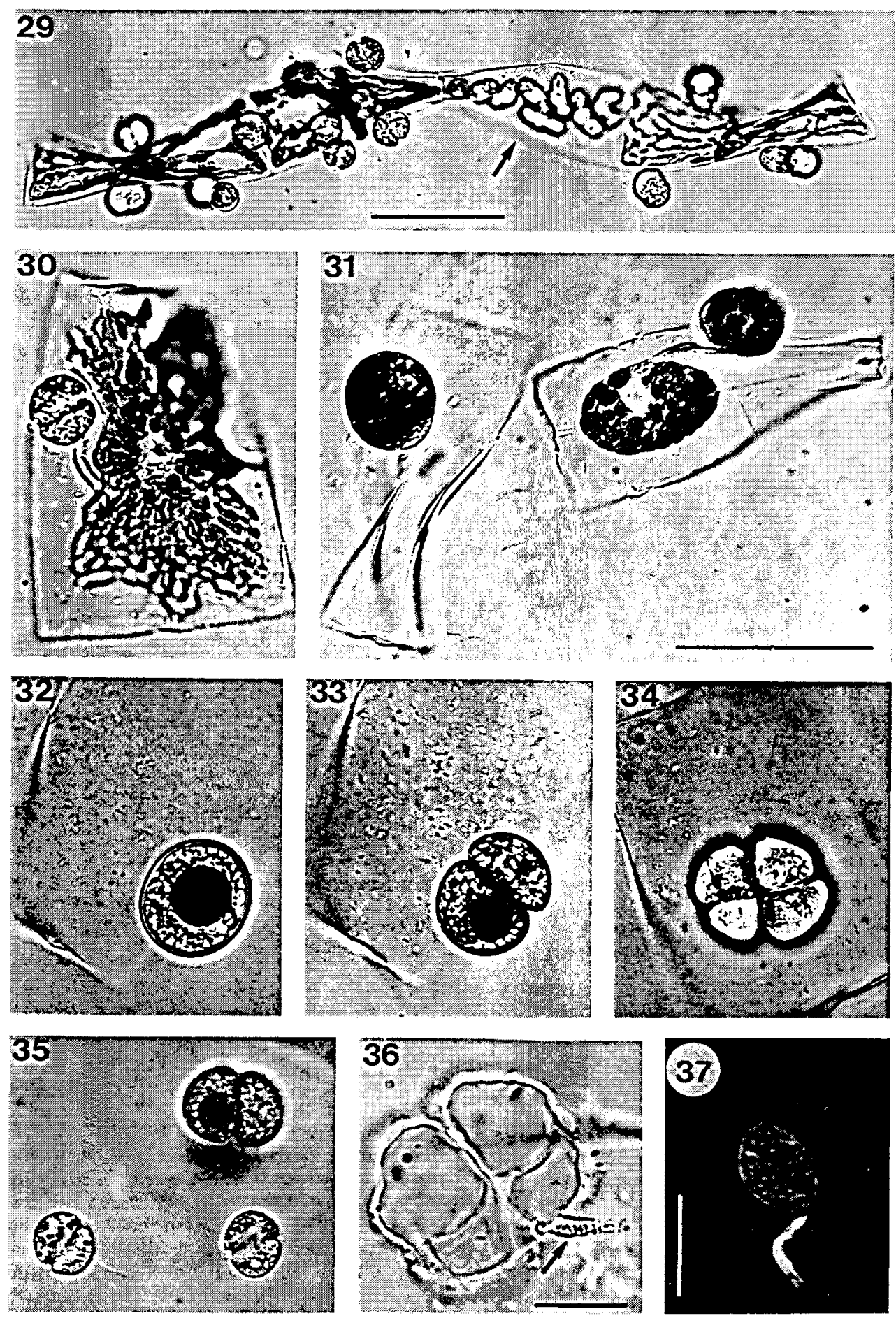



Figs 38-41. Paulsenella vonstoschii on Streptotheca thamesis. Fig. 38. Primary cyst in nuclear cyclosis. To the left in comparison a vegetative primary cyst. Fig. 39. Primary cyst in nuclear cyclosis, stained with iron carmine acetic acid. To the right a small vegetative primary cyst. Fig. 40. Two (meio-) secondary cysts formed after the first meiotic division. Fig. 41. Three resting cysts derived from meiospores. On the right (above) a temporary cyst. Figs $38,40,41$ : Scale bar $=50 \mu \mathrm{m}$. Fig. 39: Scale bar $=10 \mu \mathrm{m}$

Figs 29-37. Paulsenella vonstoschil on Streptotheca thamesis. Fig. 29. Dinospores attracted only by the three vegetative cells of Streptotheca, but displaying no infestation on the sexually determined diatom cell containing spermatocytes (arrow). Fig. 30. Dinospore having penetrated the host by a peduncle, host protoplast begins to plasmolyse. Fig. 31. Trophont sucking out the host cell via a peduncle. To the left a mature trophont having completely emptied the host cell. Fig. 32. Primary cyst. Fig. 33. Two secondary cysts. Fig. 34. Four tertiary cysts. Fig. 35. Two dinospores freshly released from a tertiary cyst. Fig. 36. Empty envelopes of four tertiary cysts; the rod-like granular structure (arrow) attached as part of the peduncle. Fig. 37. Fluorescence of the feeding tube sheath in partially empty cysts after staining with Tinopal (fluorescence phase contrast). Fig. 29: Scale bar $=$ $50 \mu \mathrm{m}$. Figs 30-35: Scale bar $=50 \mu \mathrm{m}$. Fig. 36: Scale bar $=10 \mu \mathrm{m}$. Fig. 37: Scale bar $=25 \mu \mathrm{m}$ 


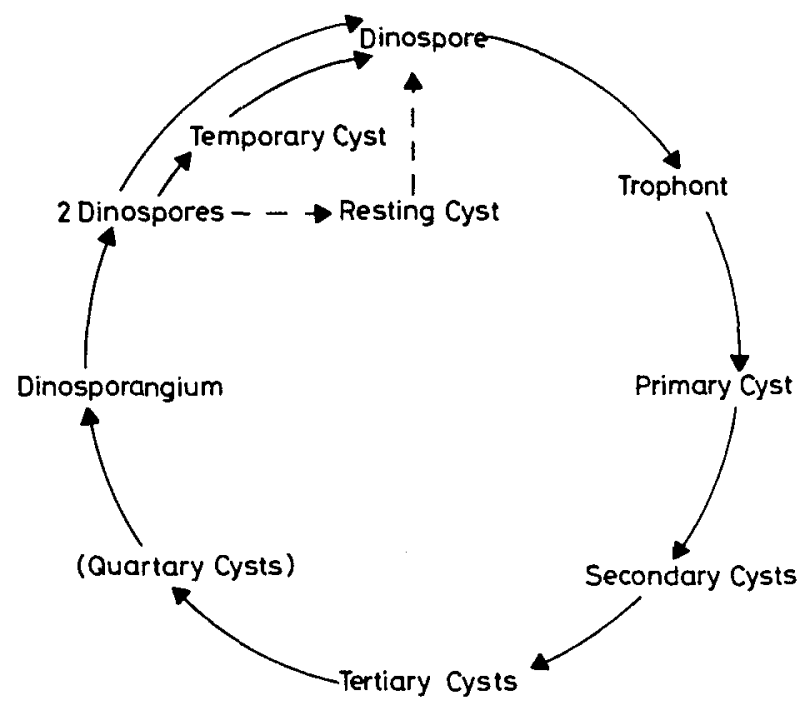

Fig. 42. Diagram of vegetative reproduction in Paulsenella. Quartary cysts are only exceptionally formed in $P$. chaetoceratis. Vegetative origin of resting cysts unproved

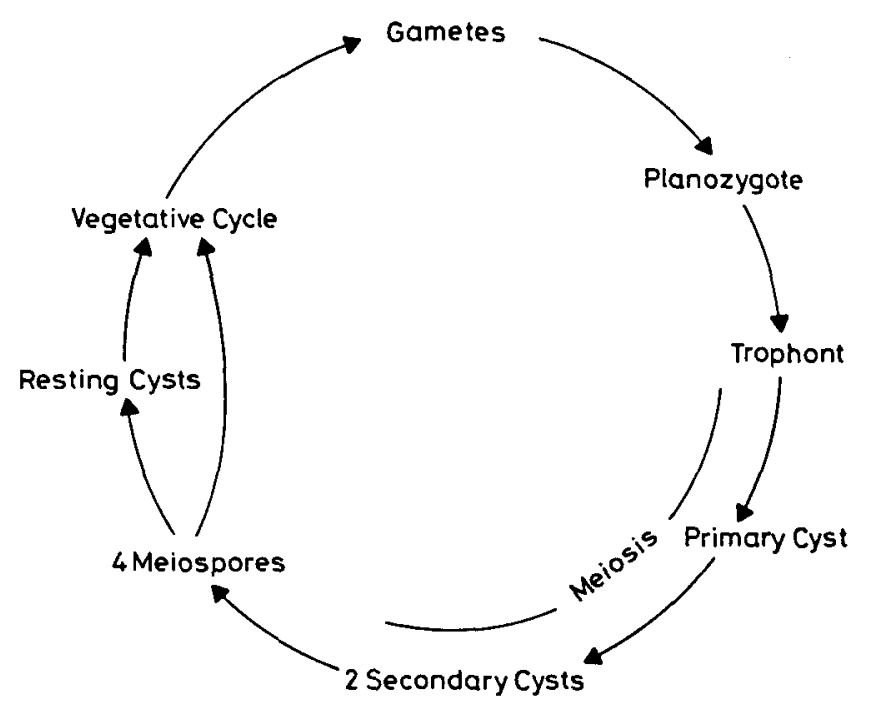

Fig. 43. Diagram of sexual reproduction in Paulsenella

also on Bellerochea malleus, Lithodesmium undulatum, and Neostreptotheca subindica. Meanwhile, R. Akselman (pers. comm.) reported natural populations of $L$. undulatum in the port of Mar del Plata as being infected by probably the same species. In Drebes (1984), a Paulsenella sp. is illustrated sticking to cells of Cerataulina pelagica, indicating presumably a further, still undescribed, parasite.

Attention must be paid to the host specificity and taxonomy of the type species, $P$. 
chaetoceratis. The Latin diagnosis given by Paulsen (1911) only includes the host Chaetoceros borealis, though he found the parasite in a single case also on $C$. decipiens. Our observations on $P$. chaetoceratis were restricted to forms parasitizing $C$. decipiens. Unexpectedly, attempts failed to get them growing on $C$. borealis as well. But it must be conceded that the few Chaetoceros chains freshly isolated from the plankton were not in optimal condition, and we did not succeed in establishing clonal culture for further trials. Thus, these short-term experiments were still insufficient to solve the question as to whether the species compatible with $C$. decipiens may be able likewise to accept $C$. borealis as a host.

The possible existence of two distinct species under the same name may be supported by Paulsen (1911), when he wrote, "The wall of the awn (= seta of C. borealis) is perforated. In Fig. G the perforation is distinctly seen." However, since the setae of these Chaetoceros species are fenestrated, the parasite does not need a self-made perforation to penetrate the cell. Perhaps Paulsen's drawing of a "perforation" was a confusion with a possible peduncle wall of the parasite. In that case, the species could be distinguished from ours, which has a wall-less peduncle. In a net sample off Helgoland (German Bight), Drebes (1974) observed only once $P$. chaetoceratis attached to $C$. borealis. Meanwhile, we doubt whether the stage presented can be related to P. chaetoceratis at all. Anyhow, a thorough re-investigation on living material of Paulsen's species is required to decide on the species' identity.

In North Sea phytoplankton, Paulsenella is found between late spring and early autumn. $P$. chaetoceratis and $P$. kornmannii are rare, whereas $P$. vonstoschii can be frequently observed on Streptotheca thamesis populations of the Wadden Sea area (Drebes \& Schnepf, 1982). In plankton samples, it is usual that only primary cysts and subsequent cyst stages of Paulsenella are encountered. In laboratory cultures, the three species exhibit their complete life cycles, including vegetative and sexual reproduction, and resting stages as well. Details of the vegetative development in $P$. vonstoschii were already provided by Drebes \& Schnepf (l.c.). Since the reproductive mode of $P$. chaetoceratis and $P$. kornmannii proved to be quite similar, Figure 42 presents the sequence of the cardinal vegetative stages applying to all three species. Species-specific characteristics mainly refer to differences in the structure of the peduncle and the trophont.

The vegetative life cycle of Paulsenella is typical of a parasite. The dinoflagellate (dinospore) loses during the "hypertrophic" (parasitic) growth phase its gymnodinoid outline and becomes a large spherical trophont. Reproduction (sporogenesis) takes place by consecutive formation of division cysts giving rise to generally more than two offspring (dinospores). In exceptional cases, such as in $P$. chaetoceratis, a single trophont may even form 8 quartary cysts resulting in 16 dinospores, obviously the highest number possible in Paulsenella.

In order to endure unfavourable conditions, especially when a host is absent, the motile dinospores may interrupt movement for a certain time by forming temporary cysts. In Dissodinium pseudolunula Swift ex Elbr. \& Drebes the dinospores are likewise able to encyst individually (Drebes, 1978). In aged Paulsenella cultures, dinospores may also develop into thick-walled resting cysts. It remains to be investigated whether these stages are facultatively formed during the vegetative life cycle, or whether they are exclusively parts of the sexual life cycle (see below). 
Knowledge on sexual reproduction in Paulsenella is still incomplete (Fig. 43). Various difficulties are encountered when studying this process. It has been impossible so far to distinguish between vegetative dinospores and motile sexual cells (gametes, planozygotes). Sexual stages occur in ageing cultures, when hosts and parasites deteriorate and dinospores begin to starve. Then, vegetative reproduction is disturbed and misdivisions cause a lot of artifacts. In consequence, one needs an experienced eye to distinguish between a motile double cell deriving from an incomplete cell division and a fusing pair of cells representing a copulation stage. Another obstacle is the difficulty in following the further fate of the zygote. As a planozygote, this stage is highly motile and regrettably - soon escapes continuous observations.

Nuclear cyclosis indicating meiosis takes place as a rule in primary cysts, in $P$. chaetoceratis even at the trophont stage already. It may be concluded that the planozygote goes through at least one trophontic stage (or more?), before meiosis takes place. In $P$. vonstoschii the direct development of the four meiospores into resting cysts could be proved several times. However, it remains an open question whether all the resting stages so far observed in the three Paulsenella species are obligatorily preceded by meiosis. On the other hand, in a few cases meiospores did not become resting cysts; instead new host cells were attacked and sucked out. Perhaps the procedure of isolation and transfer of meiotic stages into a fresh medium, in order to follow the further development on single cells, may occasionally prevent formation of resting cysts. In any case, it was found surprisingly that resting cysts of Paulsenella arise from meiospores. Possibly, the resting cysts of Dissodinium pseudolunula can also be interpreted as offspring of a meiosis (Drebes, 1981).

In contrast, in free-living dinoflagellates the resting cysts have proved to be hypnozygotes which germinate with meiosis (Stosch, 1972, 1973). Thus, at present, generalisations on the sexual process in dinoflagellates are difficult, especially if resting stages are involved. Therefore, it must be emphasized that the diagrammatic presentation of the sexual reproduction in Figure 43 only applies to Paulsenella.

Acknowledgements. We are grateful to Mrs. H. Halliger (List) for technical assistance. Dr. J. W. Kadereit (Heidelberg) kindly provided the Latin diagnoses. This work was supported by the Deutsche Forschungsgemeinschaft.

\section{LITERATURE CITED}

Aleem, A. A., 1979. Marine microplankton from Sierra Leone (West Africa). - Indian J. mar. Sci. 8, 291-295.

Chatton, E., 1920. Les péridiniens parasites. Morphologie, reproduction, éthologie. - Archs Zool. exp. gén. 59, 1-475.

Drebes, G., 1974. Marines Phytoplankton. Thieme, Stuttgart, $186 \mathrm{pp}$.

Drebes, G., 1978. Dissodinium pseudolunula (Dinophyta), a parasite on copepod eggs. - Br. phycol. J. 13, 319-327.

Drebes, G., 1981. Possible resting spores of Dissodinium pseudolunula (Dinophyta) and their relation to other taxa. - Br. phycol. J. 16, 207-215.

Drebes, G., 1984. Life cycle and host specificity of marine parasitic dinophytes. - Helgoländer Meeresunters. 37, 603-622.

Drebes, G. \& Schnepf, E., 1982. Phagotrophy and development of Paulsenella cf. chaetoceratis (Dinophyta), an ectoparasite of the diatom Streptotheca thamesis. - Helgoländer Meeresunters. $35,501-515$. 
McLachlan, J., 1973. Growth media - marine. In: Handbook of phycological methods. Culture methods and growth measurements. Ed. by J. R. Stein. Cambridge Univ. Press, Cambridge, 25-51.

Paulsen, O., 1911. Marine plankton from the East-Greenland Sea. III. Peridiniales. - Danm. Eksped. Grønlands Nordøstkyst 1906-1908, 3(11), 303-318.

Schnepf, E. \& Deichgräber, G., 1984. "Myzocytosis", a kind of endocytosis with implications to compartmentation in endosymbiosis: observations in Pausenella (Dinophyta). - Naturwissenschaften $71,218-219$.

Schnepf, E. \& Drebes, G., 1986. Chemotaxis and appetence of Paulsenella sp. (Dinophyta), an ectoparasite of the marine diatom Streptotheca thamesis Shrubsole. - Planta 167, 337-343.

Schnepf, E., Deichgräber, G. \& Drebes, G., 1985. Food uptake and the fine structure of the dinophyte Paulsenella sp., an ectoparasite of marine diatoms. - Protoplasma 124, 188-204.

Schnepf, E., Meier, R. \& Drebes, G., 1988. Stability and deformation of diatom chloroplasts during food uptake of the parasitic dinoflagellate, Paulsenella (Dinophyta). - Phycologia 27, 283-290.

Stosch, H. A. von, 1972. La signification cytologique de la "cyclose nucléaire" dans le cycle de vie des dinoflagellés. - Mém. Soc. bot. Fr. 1972, 201-212.

Stosch, H. A. von, 1973. Observations on vegetative reproduction and sexual life cycles of two freshwater dinoflagellates, Gymnodinium pseudopalustre Schiller and Woloszynskia apiculata sp. nov. - Br. phycol. J. 8, 105-134. 